\title{
Memahami Bid'ah dalam Perspektif Majelis Tarjih Alquran (MTA)
}

\author{
Mokhamad Sukron \\ Universitas Islam Negeri (UIN) Sunan Kalijaga, Jogjakarta \\ musyakir.awwy@gmail.com
}

\begin{abstract}
Abstrak
Falsehood (bid'ah) becomes an interesting study for Moslem scholars especially on the matters of worship and ritual practices. The committee of tarjîh al-Qur'ân justifies falsehood by referring to Hadith used as the guide and method. The interpretative result toward the badith causes different perspective among Moslem scholars. There are three important points that will be elucidated in this article: first what method uses MTA in conceiving hadith in relation with falsehood, second how MTA perspective of bid'ah, and third is re-construction the badith bid'ah according to MTA. MTA explains that what is called bid'ah in prophet's hadith is bid'ah in the matter of religion (worship) that certainly misleading. Yet, the falsehood in relation with worldly matter for MTA must be given a space to branch out as long as it gives positive impact and push people creativity in general meaning. It is suitable with prophet's hadith said that "man sanna sunnab hasanah.... man sanna sunnab sayyiah...". In this condition, MTA indirectly admits the variant of the bid'ah. But the ordinary classification differs with the ulama's classification either in terms of mutaqadimîn or muta'akhirin, in general point of view, otherwise the classification is in contrary with the religious matters and worldly matters.
\end{abstract}

Keywords: bid'ah, hadith, metode, MTA. 


\section{Pendahuluan}

Setiap Muslim berusaha melaksanakan semua tuntunan agamanya agar mampu mencapai derajat saleh dan bertemu dengan Allah bersama para Nabi, Rasul, Awliyâ', dan Șiddiqûn. Karena itu, terlebih dahulu harus mampu memahami dan menjalankan syariat Islam yang termaktub dalam Al-Qur'an dan hadis Nabi. Dalam memahami sebuah ayat maupun hadis terdapat beragam metode ataupun hasil pemahamannya. Perbedaan metode maupun pemahaman atas ayat atau hadis adalah, ketika memasuki ranah aksiomatik. Di sana, tidak akan terjadi perselisihan di antara sesama Muslim jika, diaplikasikan pada diri sendiri dan tanpa menyalahkan satu sama lainnya. Berbeda halnya dengan adanya pemaksaan pemahaman seseorang terhadap lainnya dan menganggap pemahaman selain dirinya salah.

Perbedaan hasil pemahaman terhadap suatu ayat maupun hadis sebetulnya telah terjadi pada masa Rasulullah masih hidup, namun hal itu segera terselesaikan dengan rapi di hadapan Rasulullah. Pada masa generasi kedua, perbedaan pemahaman bisa diselesaikan melalui forum diskusi di kalangan para sahabat Nabi dan hal tersebut terus berlanjut pada masa-masa sesudahnya. Hal yang mengherankan adalah pada masa kini menyalahkan satu sama lainnya antara sesama Muslim adalah menjadi hal lumrah bahkan saling mengkafirkan, sehingga tidak jarang terjadi pertumpahan darah di antara sesama umat Islam. Di antara terjadinya hal-hal semacam itu adalah pemahaman tentang hadis-hadis

bidah. Selain di Jazirah Arab sendiri, perbedaan pemahaman hadis-hadis bidah juga terjadi di Indonesia. Perbedaan pemahaman tersebut tidak hanya terjadi dalam masyarakat Islam Indonesia dan antar organisasi Islam saja, bahkan dalam satu organisasi keislaman pun tidak terelakkan.

Di antara perbedaan pemahaman hadis-hadis bidah yang menjadi salah satu faktor konflik di masyarakat adalah pemahaman Majelis Tafsir Al-Qur'an (MTA) dan Nahdlatul Ulama (NU) yang saling berseberangan, sehingga di kalangan grossroots saling mengklaim kebenaran masingmasing yang menimbulkan ketersinggungan di kalangan masyarakat NU. Sebagaimana diberitakan di Koran harian online TEMPO bahwa dakwah 
MTA telah meresahkan masyarakat terutama, di kalangan NU. ${ }^{1}$ Zainal Abidin Petir menjelaskan materi dakwah yang disampaikan ketua umum MTA Solo melalui radio oleh Ahmad Sukino menimbulkan polemik di masyarakat. Ahmad Sukino menyatakan bahwa, orang meninggal tidak perlu diperingati hari ketiga, tujuh, hingga hari ke-1000 dan tidak perlu ada ajaran tablilan maupun yasinan. Apa yang dilakukan Ahmad Sukino merupakan interpretasi pemahaman hadis-hadis tentang bidah yang beragam.

Metode yang digunakan adalah metode tematik (mawdûn yakni, fokus meneliti hadis-hadis yang digunakan oleh MTA dalam permasalahan bid'ah dan variannya. Penulis juga mendeskripsikan seluruh hadis-hadis tentang bid'ah perspektif MTA beserta metodologi sharah dan keautentikan hadisnya. Terakhir merekonstruksi ulang pemahaman hadis-hadis bid'ah dengan mengkaji dua aspek yakni, autentisitas hadis jalur sanad dan matan serta pemahaman hadis untuk membuktikan kekonsistenan MTA dalam menggunakan metodologi sharah dan pengujian autentisitas hadis.

Penyeleksian dari jalur sanad menggunakan teori-teori sanad pada umumnya (mayoritas ulama hadis), namun ketika menganalisis tingkatan jarḥ dan ta'dîl merujuk pada kualifikasi tingkatan yang dilakukan oleh Riḍâ Zakarîyâ Muḥammad 'Abd Allâh Hamidah. ${ }^{2}$ Pada penyeleksian dari jalur matan merujuk pada teorinya Muhammad al-Ghazali.

${ }^{1}$ Rofiuddin, "Melarang Tahlilan, KPI Jawa Tengah Tegur Radio MTA Solo", dalam Tempo Online (28 Mei 2009), http://www.tempo.co/read/news./diakses 29 Oktober 2013.

${ }^{2}$ Yakni membagi tingkatan 6 tingkatan untuk ta'dîl dan 6 tingkatan untuk jarh. Adapun dilihat dari derajat ta'dîl adalah derajat pertama samapai ketiga hadisnya sabîh dan dijadikan bujjah. Sedangkan derajat keempat hadisnya ḥasan li dhâtih. Derajat ta'dîl kelima dan keenam hadisnya da'î́f yang mana jika ada mutabi'ât dan shawâhid maka hadisnya menjadi hasan li ghayrih. Sedangkan Hadis-hadis yang diriwayatkan oleh râwi abl marâtib al-tajrîh al-ḍa iffah sebagian bisa diamalkan selagi ada shawâbid dan mutabi ât (derajat tajrîh pertama samapi ketiga), sebagian tidak bisa dibantu dengan shawâhid dan mutabi'ât (derajat tajrîh keempat) dan sebagian lagi tidak bisa diamalkan sama sekali (derajat tajrîh kelima dan keenam). Lihat Rị̣â Zakarîyâ Muhammad 'Abd Allâh Ḥamidah, Al-Irshâd Ilâ Kayfî̀ah Dirâsat al-Isnâd (Kairo: Maktabah al-Imân, 2008), 154-206. 
Kemudian, dalam merekonstruksi pemahaman hadis, menggunakan hermeneutika hadis dari teori hermeneutika Al-Qur'an oleh Fazlur Rahman yaitu, teori Gerakan Ganda (double movement). Teori tersebut menjelaskan bahwa gerakan ganda merupakan langkah menelusuri dari situasi kini kepada situasi Nabi, yang bersabda, dan kemudian kembali dari lampau kepada masa kini. ${ }^{3}$

Gerakan kembali kepada situasi Nabi ada dua langkah yang diperlukan. Pertama, memahami makna hadis sebenar-benarnya dengan mengkaji situasi atau problem historis yang ingin dijawabnya. Namun, sebelumnya perlu dikaji juga situasi makro dalam batasan-batasan masyarakat, agama, adat-istiadat, lembaga bahkan keseluruhan kehidupan masyarakat di Arab pada saat Islam datang, khususnya Makkah dan sekitarnya.

Kedua, menggeneralisasikan respons spesifik sabda Nabi Saw dan menyatakannya sebagai ungkapan yang memiliki tujuan moral sosial umum berdasarkan latar belakang sosio-historis dan unsur ratio legis ('illat al-buk.m) yang dikandungnya. Bersamaan dengan itu, ajaran hadis harus dipahami sebagai suatu keseluruhan, sehingga setiap arti yang dipahami, setiap hukum yang dinyatakan dan setiap tujuan yang dirumuskan akan saling koheren satu sama lain. ${ }^{4}$

Dari yang umum kepada yang khusus merupakan upaya penerapan rumusan prinsip-prinsip umum, nilai-nilai dan tujuan-tujuan (ideal moral) hadis pada situasi aktual sekarang ini. Dalam gerakan ini terdapat dua kerja yang saling berkaitan. Pertama, merumuskan prinsip umum Al-Qur'an menjadi rumusan-rumusan spesifik dengan mempertimbangkan konteks sosio-historis yang kongkret. Kedua, memahami kehidupan aktual yang sedang berkembang dalam berbagai aspeknya; ekonomi, politik, kebudayaan dan lain-lain secara akurat. ${ }^{5}$

\section{Majlis Tarjih Al-Qur'an (MTA) di Solo}

\footnotetext{
${ }^{3}$ Mawardi, "Hermeneutika Al-Qur'an Fazlur Rahman", dalam Sahiron Syamsudin (ed.), Hermeneutika Al-Qur'an dan Hadis (Yogyakarta: eLSAQ Press, 2010), 70.

${ }^{4}$ Ibid.

${ }^{5}$ Ibid.
} 
Melihat sosio agama masyarakat Solo dan sekitarnya, di mana masih banyak praktik sinkretisme, animisme, dinamisme, Hinduisme dan Buddhisme yang merasuk dalam masyarakat Muslim dengan menambahkan ayat-ayat suci Alquran dan lain sebagainya, Ust. Abdullah Thufail Saputro prihatin dan tergugah untuk mengajak merekan dan berdakwah ke jalan yang benar, yakni kembali kepada Alquran dan Sunah Nabi. Dakwah tersebut dimulai dengan merintis pengajian di Nahḍatul Muslimat Kauman dan Pengajian Tauhid pada setiap Ahad pagi di Kemlayan Serengan Surakarta. Selain mengisi di dua tempat tersebut, Ust. Abdullah Thufail Saputro juga aktif mengisi pengajian di Majelis Pengajian Islam (MPI) yang dipimpin oleh Abdullah Marzuki dan pengajian-pengajian lainnya. ${ }^{6}$

Dari aktivitas dakwahnya di beberapa pengajian, Ust. Abdullah Thufail Saputro mempunyai keinginan yang luhur yakni, membentuk suatu wadah dakwah Islam yang menyerukan umat mengkaji Alquran dan Sunah secara kontinu dengan mengundang ormas-ormas Islam seperti Nahdhatul Ulama, Muhammadiyah, PSII, Al-Irsyad dan MUI. Setelah melakukan pertemuan sebanyak tiga kali, ide Ust. Abdullah Thufail Saputro pupus dikarenakan tidak menemukan kesepakatan di antara ormas-ormas tersebut dan memilih untuk berdakwah sendirisendiri sehingga beliau mengalihkan dengan membentuk jamaah pengajian. Pada awalnya, pengajian ini hanya diikuti oleh tujuh siswa yang pernah mengaji di Pengajian Angkatan Muda Islam Nahdhatul Muslimat Kauman. Karena ketujuh murid tersebut terkesan dengan pengajian yang disampaikan oleh Ust. Abdullah Thufail Saputro, maka mereka meminta untuk dilanjutkan pada minggu-minggu berikutnya diadakan di kampung Semanggi Pasar Kliwon.

Sepeninggal Ust. Abdullah Thufail Saputro kepemimpinan MTA diamanatkan kepada Ahmad Sukina. Beliau adalah murid generasi pertama dan murid yang terdekat yang selalu menyertai Ust. Abdullah Thufail Saputuro. Pada masa Ahmad Sukina ini MTA mengalami perkembangan yang cukup signifikan dalam berbagai lini terutama

\footnotetext{
6 Mutohharun Jinan, "Kepemimpinan Imamah dalam Gerakan Purifikasi Islam di Pedesaan, (Tesis-UIN Sunan Kalijaga Yogyakarta, 2013), 82-83. Lihat juga Profil Yayasan Majlis Tafsir Al Qur'an (MTA), CD-ROM.
} 
perkembangan pengikut di berbagai penjuru nusantara. Jinan membagi perkembangan MTA di masa kepemimpinan Ahmad Sukina menjadi dua tahap, yakni tahap pemantapan dan tahap perluasan. ${ }^{7}$ Tahap pemantapan adalah tahapan MTA memantapkan diri sebagai gerakan keagamaan yang lebih terbuka dengan membuka berbagai macam usaha sehingga dakwahnya tidak hanya terpaku melalui pengajian saja tetapi, juga melalui berbagai media dakwah seperti sekolah, jaringan bisnis, penerbitan, majalah, koperasi simpan pinjam syariah, balai pengobatan dan lainnya.

\section{Memahami Bid'ah}

Bidah secara etimologi, sebagaimana dijelaskan oleh Ibn Manzûr berasal dari kata bada'a: bad' al-shay' yabda'ub bad'an wa ibtada'ah yang mempunyai makna ansha'ah wa bada'ah yakni mengadakan, menjadikan, menciptakan dan memulai. Kemudian kata al-badî' dan al-bid'u adalah alshay' al-ladhî yakîn awalan yakni sesuatu yang pertama. Sedangkan al-Bid'ah adalah al-ḥadas wa mâ ubtudi' min al-dìn ba'd ikmâl, yakni sesuatu yang baru dan hal yang baru tersebut merupakan permasalahan agama setelah agama dinyatakan sempurna. ${ }^{8}$ Sedangkan secara epistemologi, sebagaimana dijelaskan oleh Ibn Taymîyah menjelaskan bahwa bidah merupakan hal yang bertentangan dengan teks-teks agama (nusîs.s). Menurut al-'Iz bin 'Abd al-Salâm mendefinisikan bidah sebagai mengerjakan sesuatu yang tidak ada dan tidak dikenal di zaman Nabi. Sementara Ibn Hajar memberikan definisi bidah dengan mengategorikan dengan hal baru yang diciptakan namun tidak memiliki dalil dalam syariat.' 'Abd Ailâh bin Ḥusayn al-'Afraj mendefinisikan bidah yang termasuk dalam syariat adalah hal-hal baru yang diciptakan bertentangan dengan kaidah-kaidah agama Islam dan bertentangan dengan teksteksnya (nusîs.s). Hal-hal baru tersebut hanya berhubungan dengan urusan agama dan bukan berkaitan dengan kehidupan yang sangat ditentukan oleh kemaslahatan manusia dan keberlangsungan hidupnya. Bidah yang

\footnotetext{
7 Jinan, “Kepemimpinan Imamah”, 108-111.

8 Ibn Manzûr, Lisân al-'Arab, Vol. 8 (Beirut: Dâr Ṣâdir, 1414 H), 6.

9 'Abd Ilâh bin Husayn al-'Afraj, Konsep Bid'ah dan Toleransi Fiqih, terj. Mohamad Taufiq Q. Hulaimi dkk. (Jakarta: Al-I’tishom, 2013), 12.
} 
seperti ini, menurut beliau, adalah bidah yang sesat. ${ }^{10}$ Menurut Hasyim Asy'ari bidah adalah perkara yang baru dalam masalah agama yang seakan-akan bagian dari agama padahal bukan baik secara hakikat maupun secara bentuknya dan tidak ada dalil shar $\hat{\imath}$-nya. ${ }^{11}$

Dari uraian definisi bid'ah beberapa ulama baik klasik atau kontemporer dapat disimpulkan bahwa bidah secara istilah sharî̀ adalah hal-hal baru, di mana hal baru tersebut merupakan urusan agama bukan urusan dunia, yang diciptakan yang tidak termaktub atau bahkan tidak merepresentasikan inti dalam Alquran maupun hadis Nabi atau tidak ada dalil atau nas sharî. Sehingga jika ada orang mendakwakan bahwa amalannya merupakan bukan Bidah atau bid'ah hasanah maka perlu

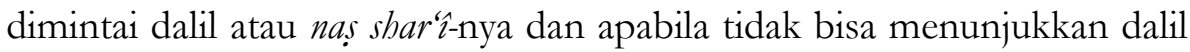
atau nas sharînya secara jelas atau setidaknya tidak memiliki representasi terhadap keduanya maka amalannya dianggap bidah yang sesat.

\section{Bid'ah Menurut Majlis Tarjih Al-Qur'an}

Bidah menurut definisi MTA, sebagaimana yang dijelaskan oleh Masduki, adalah sesuatu yang baru atau suatu aturan-aturan yang dahulu belum ada kemudian dianggap sebagai syariat. ${ }^{12}$ Ahmad Sukina menjelaskan bahwa yang dinamakan bidah adalah suatu ibadah yang di masa Nabi dan setelah Nabi wafat serta di masa para sahabat tidak pernah dilakukan sedangkan kita melakukan ibadah tersebut dengan anggapan hal itu merupakan bagian dari syariat. ${ }^{13}$ Dan ibadah yang tidak ada di masa Nabi dan sahabat tersebut merupakan sejelek-jelek perkara yang diada-adakan sehingga masuk kategori bidah yang menjadikan pelaku masuk neraka. ${ }^{14}$

Masduki menjelaskan secara lanjut bahwa ketika kita melakukan hal-hal yang baru (belum ada di zaman Nabi dan di zaman sahabat Nabi)

\footnotetext{
10 Ibid, 36.

11 Hasyim Asy'ari, Risalah Abl as-Sunnah, terj. A. Zainul Hakim, 7-14, www.kangridho.blogspot.com/ diakses 03 Mei 2014.

12 Masduki, Wawancara, 27 April 2014.

13 Pengajian Ahad Pagi pada tanggal 20 Januari 2008 dalam file MP3.

14 Ahmad Sukina, Wawancara, 08 Mei 2014.
} 
namun, mempunyai bujjah atau dalil dari Alquran dan Sunah Nabi maka hal-hal baru tersebut bukanlah termasuk bidah. ${ }^{15}$ Dengan demikian, yang dinamakan bidah adalah sesuatu yang baru yang tidak ada di zaman Nabi dan zaman sahabat Nabi serta tidak mempunyai bujjah atau dalil dari Alquran dan Sunah Nabi di mana hal baru tersebut dianggap bagian dari syariat Islam. Hal itu sesuai dengan hadis Nabi yang diriwayatkan oleh Jâbir bin 'Abd Allâh, Inn aṣdaq al-ḥadîth kitâb Allâh wa ạ̣san al-bady muhammad wa sharr al-umûr muḅdathâtubâ wa kull muhdathah bid'ah wa kull bid'ah dalâlah wa kull dalâl fî̀ al-nâr ${ }^{16}$ (Sesungguhnya sebenar-benar perkataan ialah kitab Allah, sebaik-baik petunjuk ialah petunjuk Muhammad, sejelek-jelek perkara itu yang diada-adakan, tiap-tiap yang diada-adakan itu bidah, tiap-tiap bidah itu sesat dan tiap-tiap kesesatan itu di neraka).

'Âishah juga meriwayatkan sabda dari Nabi yang menyatakan tertoaknya amal perbuatan yang dilakukan bukan atas perintah Nabi Muhammad, Man 'amil 'amalan lays 'alayh amrunâ fa buwa radd ${ }^{17}$ (Barang siapa yang melakukan suatu amalan yang bukan perintah kami maka, ia tertolak). Hudhayfah juga meriwayatkan hadis Nabi yang menjelaskan bahwa ibadah-ibadah yang dilakukan oleh para pelaku bidah ditolak oleh Allah, Lâ yaqbal Allâh li șâhib bid'ah sawman wa lâ șalâtan wa lâ sadâqatan wa lâ hajjan wa lâ 'umratan wa la jïhâdan wa lâ șarfan wa lâ 'adlan yakhruj min alislâm kamâ takbruj al-sha'rah min al-'ajîn ${ }^{18}$ (Allah tidak mau menerima dari orang ahli bidah akan puasanya, salatnya, sedekahnya, hajinya, umrahnya, jihadnya, tobatnya dan tidak pula tebusannya. Ia telah keluar dari Islam seperti keluarnya sehelai rambut dari adonan tepung). Demikian halnya hadis yang diriwayatkan oleh 'Abd Allâh bin Mas'ûd, Anâ faratukum 'alâ

\footnotetext{
15 Masduki, Wawancara, 27 April 2014.

${ }^{16}$ Hadis riwayat al-Nasâ'î dalam kitab Sunan al-Nasầ, Vol. 3, hadis no. 1578 yang dikutip dalam Majelis Tafsir Al-Qur'an (MTA), Kumpulan Brosur-Brosur Pengajian Abad Pagi Sunnah dan Bid'ah (Surakarta: MTA [Majelis Tafsir Al-Qur'an], t.th), 24.

${ }^{17}$ Hadis riwayat Muslim dalam kitab Șahîh Muslim, Vol. 3, hadis no. 1718 yang dikutip dalam Majelis Tafsir Al-Qur'an (MTA), Kumpulan Brosur-Brosur Pengajian Ahad Pagi Sunnah dan Bid'ah, 28.

18 Hadis riwayat Ibn Mâjah dalam kitab Sunan Ibn Mâjjah, Vol. 1, hadis no. 49 yang dikutip dalam Majelis Tafsir Al-Qur'an (MTA), Kumpulan Brosur-Brosur Pengajian Abad Pagi Sunnah dan Bid'ah, 30-31.
} 
al-ḥawd layurfa'anna ilayya rijâl minkum ḥatta idhâ abwaytu liunâwilabum ukbtulijû dînî, fa aqûl ayy rabb așhâbî yaqûl lâ tadrî mâ aḅdatû ba daka ${ }^{19}$ (Aku adalah pendahulu kalian semua di telaga (hawd). Sesungguhnya ada orangorang di antara kalian yang diangkat kepadaku sehingga ketika aku mengulurkan (tangan) untuk menjangkau mereka seketika mereka ditarik dariku, lalu aku berseru wahai Tuhanku, mereka itu umatku. Allah berfirman, "kamu tidak tahu apa yang mereka lakukan sesudahmu".

Hadis riwayat 'Âishah di atas harus diperhatikan bahwa kata kull dalam kalimat kull bid'atin dalâlah adalah keseluruhan bukan bermakna kebanyakan sehingga seluruh bidah adalah sesat dan sesat akan masuk neraka. $^{20}$

Hal senada juga diungkapkan oleh Yoyok Sugiyatna dan Ahmad Sukina bahwa bidah secara syariat hanya ada satu yakni, bid'ah d̦alâlah. Majelis Tafsir Alquran (MTA) sendiri tidak sependapat dengan pendapat yang menyatakan bahwa bidah dalam syariat itu terbagi menjadi berbagai varian seperti bid'ah ḥasanah, bid'ah dalâlah, bid'ah wâjib, bid'ah sunnah, bid'ah mubâh, bid'ah makeruh, dan bid'ah harâm. Adapun jika MTA berbeda pendapat dan pandangan dalam masalah ini adalah absah. Namun MTA akan menghormati semua pendapat dan pandangan yang ada karena berpedoman pada ayat Lanâ a'mâlunâ walakum a'mâlukum, sehingga jika (perbuatan yang dianggap bid'ah hasanah misalnya) itu merupakan pahala berarti pahala itu milikmu dan jika sebaliknya maka dosa milikmu. ${ }^{21}$ Kemudian, bidah atau hal-hal baru yang bersifat duniawi (bukan berkaitan dengan ibadah) bagi MTA justru harus didukung dan dikembangkan sebagaimana dijelaskan dalam hadis Nabi, "Barangsiapa yang mengadakan suatu cara yang baik di dalam Islam lalu (cara itu) diikuti orang sesudahnya maka ditulis pahala baginya sebanyak pahala orang-orang yang mengikutinya dengan tidak kurang sedikit pun dari pahala mereka. Dan barang siapa yang mengadakan suatu cara yang

${ }^{19}$ Hadis riwayat Imam Bukhari dalam kitab Șaḥ̂h al-Bukhârî, Vol. 9, hadis no. 7049 yang dikutip dalam Majelis Tafsir Al-Qur'an (MTA), Kumpulan Brosur-Brosur Pengajian Ahad Pagi Sunnah dan Bid'ah, 34.

20 Masduki, Wawancara, 27 April 2014.

21 Ahmad Sukina, Wawancara, 30 Maret 2014; Yoyok Sugiyatma, Wawancara, 27 April 2014. 
buruk di dalam Islam lalu (cara itu) diikuti orang sesudahnya maka ditulis pahala baginya sebanyak pahala orang-orang yang mengikutinya dengan tidak kurang sedikit pun dari dosa mereka".22

Ahmad Sukina memberikan penjelasan lebih lanjut hadis di atas bahwa, maksudnya adalah Sunah (cara yang diadakan) yang berkenaan dengan hal-hal bersifat duniawi saja, yakni mengadakan sesuatu yang bermanfaat bagi manusia di dalam Islam sangat dihargai dan diperintahkan dalam urusan dunia agar kita selalu kreatif. Jika kita (sebagai orang Islam) menelurkan hasil kreativitas yang bermanfaat maka pahalanya akan kita dapat sebanyak pahala orang-orang yang mengikutinya dengan tidak kurang sedikit pun dari pahala mereka seperti kreativitas orang yang menemukan mesin perontok padi yang sangat bermanfaat bagi orang banyak. Beliau melanjutkan, bahwa ketika hal-hal yang berkaitan dengan ibadah jangan melakukan kreativitas dengan merubah-rubah ibadah karena ibadah itu sudah paten dan kita diperintahkan hanya mengikuti saja tidak boleh menciptakan atau membuat cara sendiri. Adapun hal-hal yang bisa mendekatkan diri kepada Allah. adalah dengan mengikuti cara-cara yang dilakukan oleh Nabi karena ia yang paling tahu cara untuk mendekatkan diri kepada Allah. ${ }^{23}$

Mengenai batasan antara urusan dunia dan urusan agama, menurut Ahmad Sukina, terletak pada ritual peribadatan agama Islam, di mana ritual tersebut harus berdasar dari Alquran dan hadis yang sahih. Walaupun ketika seorang muslim melakukan segala aktivitas kesehariannya di luar ritual peribadatan Islam seperti bekerja dengan niat beribadah bukan berarti hal tersebut masuk ritual peribadatan akan tetapi, nilai atau esensi bekerjanya sama dengan pahala orang melakukan ritual peribadatan Islam. ${ }^{24} \mathrm{Hal}$ itu jelas sekali diterangkan dalam hadis Nabi yang diriwayatkan 'Umar bin al-Kattâb, Innmâ al-a'mâl bi al-niyât wa

22 Muslim b al-Ḥajjaj, Al-Jâmi al-Ṣahîh, Vol. 2 (Beirut: Dâr Ahyầ' al-Turâth al-'Arabî, t.th.), 704 .

23 Penjelasan brosur sunnah dan bidah pertemuan kesatu oleh Ahmad Sukina dalam pengajian Ahad Pagi pada 25 November 2007 dalam file MP3 dan Ahmad Sukina, Wawancara, 08 Mei 2014.

${ }^{24}$ Ibid. 
innamâ likull imri' mâ nawâ fa man kânat bijratub ilâ dunyâ yusî̉bubâ aw ilâ imra'ah yankihuhâ fahijratuh ilâ mâ hajara ilay h' ${ }^{25}$ (Sesungguhnya perbuatan ditentukan dengan niat dan setiap orang mempunyai niat, barang siapa hijrahnya dikarenakan hal dunia atau dikarenakan perempuan yang dinikahinya maka hijrahnya tergantung dengan niatan hijrahnya).

Batasan antara urusan dunia dan urusan agama juga dijelaskan dalam QS. Âl 'Imrân ayat 31, "Katakanlah: Jika kamu (benar-benar) mencintai Allah, ikutilah aku, niscaya Allah mengasihi dan mengampuni dosa-dosamu. Allah Maha Pengampun lagi Maha Penyayang". ${ }^{26}$ demikian juga dengan hadis Nabi yang menerangkan tata cara melaksanakan salat,

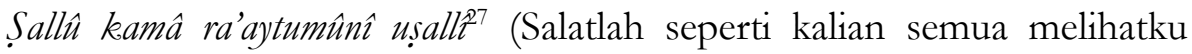
salat).

Sedangkan mengenai urusan dunia Nabi sudah menyerahkan sepenuhnya kepada masing-masing individu Muslimin, sehingga muncullah kaidah al-asl fî al-íbâdah al-ittibâ' dengan artian ketika hal yang berkaitan dengan ibadah harus dicari tuntunannya bukan dicari larangannya dan hal yang berkaitan dengan dunia maka dicarilah larangannya.

Dengan begitu, sangat jelas batasan-batasan antara urusan dunia dan urusan agama dan dengan batasan itu kita bisa membedakan mana yang termasuk kategori bidah sharî̀ dan mana yang berkaitan dengan urusan dunia. Kaitannya dengan bidah MTA tidak akan menghakimi pelaku bidah akan masuk neraka tetapi lebih menekankan pada seluruh kalangan masyarakat mengajak agar tidak menjadi pelaku bidah dan mengamalkan Alquran dan Sunah Nabi dalam kehidupan sehari-hari khususnya ritual peribadatan Islam harus berlandaskan keduanya karena tugas seorang muslim adalah saling mengingatkan dan berwasiat dalam hal kebenaran dan kesabaran. ${ }^{28}$

\footnotetext{
${ }^{25}$ Muhammad b. Ismấîl al-Bukhârî, Al-Jâmi' al-Ṣahîh, Vol. 1 (Kairo: Dâr Ṭawq al-Najâh, 1422), 6 .

${ }^{26}$ Departemen Agama RI, Al-Qur'an dan Terjemahannya (Jakarta: Darus Sunnah, 2002), 55.

27 al-Bukhârî, Al-Jâmi al-Șahîh, Vol. 8, 72.

28 Masduki, Wawancara, 08 Mei 2014.
} 
Dari penjabaran di atas, istilah bidah secara sharî perspektif MTA lebih cenderung masuk golongan yang pertama yang mempunyai pemahaman luas tentang bidah. Namun, ketika MTA memahami hadis riwayat Muslim yang mempunyai redaksi kull bid'atin dalâlah, kata kullun bermakna keseluruhan bukan bermakna kebanyakan. Dengan kata lain, MTA tidak sepakat dengan adanya tahssîis dalam hadis tersebut. Dengan demikian, terkait dengan kategori bidah MTA lebih identik dengan pendapat yang kedua.

Ada beberapa kegiatan masyarakat Islam Indonesia yang dianggap bidah oleh MTA. Pertama, yasinan, yakni suatu acara atau kegiatan membaca surat Yâsîn yang dilakukan oleh sekelompok masyarakat secara bersama-sama atau individu pada waktu-waktu tertentu dengan maksud tertentu seperti menghadiahkan kepada mayat, menyembuhkan orang sakit, meminta agar dimudahkan dalam sakaratul maut, sekadar berharap mendapatkan keutamaan-keutamaan dari surat Yasin atau yang lainnya. ${ }^{29}$ Yang dipermasalahkan oleh MTA adalah membaca Surat Yasin baik individu maupun kelompok dengan maksud tertentu seperti mengirimkan pahala bacaannya kepada mayat, meminta agar dimudahkan dalam sakaratul maut, membaca di makam, sekadar berharap mendapatkan keutamaan-keutamaan dari surat Yasin (mengobati penyakit, agar matinya syahid, dapat pahala seperti pahala infak, dosanya diampuni dan dapat pahala seperti pahala haji berkali-kali) atau yang lainnya, di mana maksud-maksud tersebut tidak ada tuntunannya dalam Alquran maupun Sunah Nabi. Kalaupun ada yang terkait dengan keutamaan-keutamaan surat Yâsîn akan tetapi hadis-hadis yang terkait dengan keutamaan-keutamaan surat Yâsîn semua da îf bahkan ada yang mawdûn sehingga tidak bisa dijadikan landasan dalam beribadah. ${ }^{30}$

Kedua, tablilan. Menurut MTA tablilan dan tablil adalah hal yang berbeda. Tablil adalah zikir yang paling utama di antara zikir-zikir yang

\footnotetext{
${ }^{29}$ Definisi ini merupakan definisi yang diasumsikan oleh penulis sendiri dari realitas kegiatan masyarakat Islam Indonesia yang sering melakukan hal tersebut.

30 Pengajian Ahad Pagi pada tanggal 25 November 2007, 2 Desember 2007, 03 dan 10 Febuari 2008, 27 Januari 2014; Ahmad Sukina, Wawancara, 30 Maret 2014; dan Masduki, Wawancara, 8 Mei 2014.
} 
lain. Tablil sangat dianjurkan oleh Islam dan sudah barang tentu ada tuntunannya sebagaimana firman Allah yang memerintahkan umat Islam agar selalu zikir kepada-Nya sebanyak-banyak baik di pagi hari maupun di sore hari dalam QS. al-Aḥzâb [33]: 41-42. ${ }^{31}$ Sedangkan tablilan adalah sebagaimana apa yang dipahami oleh orang Jawa pada umumnya dan biasanya bacaan tablil dibacakan pada saat acara kematian seperti peringatan tujuh hari, empat puluh hari, seratus hari, seribu hari dan lain sebagainya, di mana itu bukan ajaran Islam namun ajaran agama Hindu. Peringatan-peringatan ajaran agama Hindu tersebut bacaan-bacaannya diganti dengan bacaan-bacaan dari agama Islam oleh ulama-ulama terdahulu, yakni bacaan tablil dan zikir lainnya sehingga ritual tersebut disebut dengan tahlilan, di mana bacaan-bacaan tahlil tersebut dikirimkan kepada mayat disertai dengan hadiah fatihah dengan sighat ilâ badratî Nabî Muhammad... dan seterusnya. Dengan pengertian seperti itu tahlilan bagi MTA adalah suatu ritual yang tidak ada tuntunannya dalam Islam dan tidak pernah dilakukan oleh Nabi dan sahabatnya atau tidak pernah ada di zaman Nabi sehingga ritual itu dianggap bidah.

Ketiga, tawasul. Tawasul secara bahasa adalah suatu hal yang dapat mendekatkan diri kepada yang lain. ${ }^{32}$ Sedangkan tawasul secara istilah shara' adalah ketika seseorang mempersembahkan sesuatu kepada Allah sebagai bentuk pendekatan diri kepada-Nya agar doanya dipenuhi seperti berdoa dengan wasilah al-asmâ' al-husnâ. Sedangkan menurut MTA yang dinamakan tawasul adalah sebuah jalan mendekatkan diri kepada Allah. dan dalam mencari jalan untuk mendekatkan diri kepada Allah tidak melalui orang mati melainkan dengan amal saleh kita sendiri sebagaimana firman Allah dalam QS. Sabâ' [34]: 37. ${ }^{33}$ Sehingga, jika ber-tawassul kepada selain amal saleh kita sendiri, maka bagian dari bidah.

Keempat, talgin secara istilah, menurut MTA, adalah menuntun orang yang sedang sakarat al-mawt untuk mengucapkan kalimat lâ ilâha illâ

\footnotetext{
31 Ahmad Sakina, Wawancara, 8 Mei 2014.

32 Ibn Manzûur, Lisân al-'Arab, Vol. 11, 724-725.

33 Pengajian Ahad Pagi tanggal 25 November 2007 dalam file MP3.
} 
Allâh bukan menuntut kalimat kalimat-kalimat tayyibah ketika sudah meninggal atau sudah dikubur. ${ }^{34}$

Kelima, ziarah kubur, seorang Muslim ziarah kubur melebihi dari mengingat mati dan salam. Karena itu, tidak ada tuntunannya dalam Islam seperti: salat, membaca ayat-ayat atau surat dari Alquran di makam terlebih dengan maksud-maksud tertentu dan mengharapkan barakah mayat. Seharusnya kita diperintahkan untuk menyinari rumah dengan bacaan Alquran agar terhindar dari perbuatan syirik (menyekutukan Allah).

Keenam, zikir, doa berjamaah dan Takbiran. ketika melaksanakan salat bersama juga melakukan zikir bersama di mana sang imam berzikir dengan suara sedikit keras dengan harapan diikuti oleh jamaah makmumnya sehingga zikir berjamaah saling bersahutan hingga doa bahkan bershalawat bersama sebelum kembali meneruskan aktivitasnya masing-masing. Dalam keadaan berzikir, baik berjamaah maupun sendirian, juga kita sering temukan orang menghitung zikirannya dengan tasbih. Fenomena semacan itulah sekarang ini mulai banyak yang menyangsikannya, sehingga tidak jarang dengan lantang bahwa hal itu merupakan suatu perilaku bidah. Selain itu juga, fenomena lainnya yang mempunyai kriteria bidah adalah melakukan takbiran di malam hari raya Idul fitri baik yang ada di masjid-masjid maupun dengan keliling kampung dengan musik bedug dan shalawatan diiringi musik. Fenomena-fenomena semacam itu MTA juga mempunyai pandangan tersendiri dalam menyikapinya. Menurut MTA, ketika seseorang salaman setelah salat tidak apa-apa jika tadi sebelum salat belum salaman kanan kiri dan jika melakukannya berkali-kali (sebelum dan sesudah salat dengan orang yang sama) itu tidak ada tuntunannya dalam Islam. Dan ketika seseorang melakukan zikir setelah salat dengan menghitung bilangan zikirnya dengan tasbih maka hal itu sah-sah saja jika digunakan sebagai alat menghitung bahkan tidak hanya dengan tasbih tetapi juga dengan kerikil, lidi ataupun alat hitung lainnya. Karena yang terpenting dalam berzikir adalah hitungannya bukan alat hitungnya seperti menghitung zikir sehabis salat Subhâan Allahh, al-Hamd li Allâh, Allâh Akbar

\footnotetext{
34 Ahmad Sukina, Wawancara, 8 Mei 2014.
} 
sebanyak 33 kali. $^{35}$ Namun, ketika berzikir dan berdoa dengan suara keras, menurut MTA, merupakan bidah dan bertentangan dengan Alquran dan hadis sahih sebagaimana firman Allah dalam QS. al-A'râf [7]: 55. Begitu pula dengan takbiran di malam Idul fitri baik dalam masjid maupun keliling kampung dengan diiringi dengan musik seperti bedug dan bershalawat diiringi musik adalah bagian dari Bidah karena keduanya merupakan doa yang harus dilakukan dengan khusuk dan suara lirih. Hal yang sama juga tentang doa berjamaah selesai salat di mana imam membaca doa dan makmum membaca amin itu tidak ditemukan pada zaman Nabi dan tidak ada hadisnya.

Ketujuh, maulid Nabi. Menurut pandangan MTA sendiri berpendapat bahwa maulid Nabi adalah bidah, namun masalah bidah maulid Nabi tersebut tidak masuk dalam urusan agama tetapi dalam urusan dunia. Hal itu diungkapkan oleh Ahmad Sukina bahwa MTA menganggap bahwa Maulid Nabi adalah suatu metode dakwah Islam di mana jika metode tersebut dianggap tidak efektif maka harus dievaluasi. Namun, Ahmad Sukina sangat menyayangkan peringatan maulid Nabi justru terjebak dalam sekadar merayakan dengan mengadakan pengajian sesaat dan bershalawat yang disertai musik serta membaca al-barzanjî yang tidak ada pada zaman Nabi tanpa melihat seberapa jauh keberhasilan metode dakwah Islamnya. Sehingga kegiatan semacam itu, yakni bershalawat dan al-barzanjî, adalah suatu bentuk bidah. Kalaupun ada yang mengatakan bahwa kegiatan tersebut merupakan bentuk kecintaannya terhadap Nabi justru anggapan itu salah. Kecintaan terhadap Nabi yang benar adalah mengikuti apa yang diajarkan oleh Nabi dan mengamalkan apa yang dilakukan oleh Nabi serta mengkaji Alquran dan Sunahnya sehingga panji-panji serta syariat Islam benar-benar ditegakkan di bumi. ${ }^{36}$

Kedelapan, sedekah atas nama mayat. Selain berkeyakinan bahwa hadiah fatihah, tahlilan dan yasinan merupakan bukan bidah, masyarakat Indonesia (khususnya masyarakat Jawa) juga berkeyakinan bahwa sedekah untuk mayat yang pahalanya dihadiahkan untuknya merupakan

\footnotetext{
35 Pengajian Ahad Pagi pada tanggal 13 Januari 2008 dalam file MP3.

${ }^{36}$ Pengajian Ahad Pagi pada tanggal 25 November 2007, 3 Febuari 2008, 10 Februari 2008, 27 Januari 2014; Ahmad Sukina, Wawancara, 30 Maret 2014.
} 
kesunahan di mana sedekah tersebut diberikan ketika kenduri dilaksanakan. Menurut MTA fenomena tersebut bukanlah kesunahan melainkan bidah. Hal itu sesuai dengan firman Allah dalam QS. Fuṣsilat [41]: 46.

\section{Metode Majlis Tarjih Al-Qur'an dalam Memahami Konsep Bid'ah}

Dalam melakukan kajian keagamaan, ada beberapa hal yang dilakukan oleh MTA; Pertama, menentukan tema yang akan dibahas baik yang berkaitan dengan tafsir ayat Alquran maupun langsung yang berkaitan dengan hadis sesuai tema. Kedua, MTA mencari hadis-hadis sesuai tema tersebut dengan menggunakan kitab-kitab takhrij, seperti Tuhfat al-Ashrâf dan Mujam al-Mufahras dan melacaknya dalam kitab-kitab hadis mu'tabar (Șabîh al-Bukhârî, Șabîh Muslim, Sunan Abû Dâud, Sunan alTirmidhî, Sunan al-Nasầ̂, Musnad Aḅmad, Sunan Ibn Mâjah, Sunan al-Darimî dan Muwatta' Imâm Mâlik). MTA juga menemukan kitab-kitab sharh dari kitab-kitab hadis mu'tabar tersebut, seperti Fatḥ al-Bârî, Umdat al-Qârî, Irshâd al-Shârî, 'Aridat al-Aḥwadî, Tuhfat al-Aḥwadî, 'Awn al-Ma'bûd, dan lainnya. Dari kitab-kitab sharḅ tersebut MTA mengambil keterangan yang telah dijelaskan oleh shârị kitab dan dari kitab sharḥ tersebut juga diketahui kualitas sanad hadis yang berkenaan dengan tema. Ketiga, Dalam menyajikan hadis-hadis sesuai tema, MTA, hanya mencantumkan hadisnya, mukharij $>$ al-hadìth, kesahihah hadis dan terjemahan tanpa memberikan penjelasan bahwa terjemahan tersebut merupakan hasil dari terjemahan sharb hadis tersebut serta tidak mencantumkan referensinya. Keempat, Dalam pengajian rutinan, seperti Pengajian Ahad Pagi, MTA lebih menitikberatkan pada tanya jawab dan dalam memberikan penjelasannya pertama-tama mengutip ayat-ayat Alquran kemudian mengutip hadis-hadis sahih lainnya yang bisa dijadikan penjelasan atas hadis tersebut. Metode seperti itu, menurut MTA, harus dilakukan karena semua hadis Nabi Saw harus disandingkan dengan ayat-ayat Alquran untuk mengukur kesahihan sabda Nabi. Secara logikanya, ketika hadis bertentangan dengan Alquran maka dipastikan hadis tersebut bukanlah sabda Nabi. Adapun ada hadis sahih yang terlihat secara zahir bertentangan dengan Alquran maka, menurut MTA, pemahaman kita 
yang salah atau memerlukan penakwilan terhadap hadis sahih tersebut sehingga makna hadis sejalan dengan Alquran.

Dalam aplikasi pemahaman terhadap hadis-hadis tentang bidah diperoleh data bahwa MTA memahaminya bernuansa teologis, psikologis dan sosial kemasyarakatan dengan menggunakan pendekatan tekstual dan menampilkan fenomena kekinian akan tetapi, lebih menekankan pada wacana teks. Hal itu terbukti dengan pemahamannya terhadap redaksi hadis yang berbunyi kull bid'ah d̦alalah di mana kalimat kull dimaknai keseluruhan bukan kebanyakan atau mayoritas, sehingga bisa dikatakan bahwa MTA dalam memahami hadis tersebut dengan pandangan yang sempit (tekstualis).

Selain itu, MTA juga tidak sepakat dengan varian bidah sebagaimana yang diterangkan oleh ulama terdahulu seperti Imâm Shâfi $\hat{1}$, al-Suyûtî, 'Iza al-Dîn bin 'Abd al-Salâm dan lainnya, MTA beralasan bahwa yang dimaksud bidah dalam hadis Nabi adalah bidah dalam urusan agama (ibadah) yang sudah barang tentu secara keseluruhan adalah sesat dan kesesatan dalam urusan agama balasannya adalah neraka. Adapun bidah yang berkaitan dengan urusan dunia, bagi MTA, seharusnya terus diberi ruang gerak untuk berkembang selama Bidah tersebut memberikan dampak positif dan memacu kreativitas bagi masyarakat secara umum. Hal tersebut sesuai dengan hadis Nabi yang berbunyi, Man sanna sunnatan hasanatan... Dengan demikian, menurut hemat penulis, sebenarnya MTA secara tidak langsung menerima adanya varian bidah itu sendiri namun klasifikasi berbeda dengan klasifikasi bidah ulama-ulama baik mutaqadimin maupun muta'akbirin pada umumnya melainkan klasifikasinya bertolak pada urusan agama (ibadah) dan urusan dunia.

Dalam klasifikasi bidah urusan agama (ibadah) dan urusan dunia, MTA memberikan batasan di antara keduanya yakni terletak pada ritual peribadatan agama Islam, di mana ritual tersebut harus berdasar dari Alquran dan hadis yang sahih. Walaupun ketika seorang muslim melakukan segala aktivitas kesehariannya di luar ritual peribadatan Islam seperti bekerja dengan niat beribadah bukan berarti hal tersebut masuk ritual peribadatan akan tetapi nilai atau esensi bekerjanya sama dengan pahala orang melakukan ritual peribadatan Islam. 
Pemahaman bidah dengan makna sempit seperti itu akan berdampak pada isu-isu bidah yang diangkat, di antaranya adalah tentang yasinan yang mempunyai tujuan tertentu seperti mengirimkan pahala kepada mayat baik membacanya secara individu maupun berjamaah dan sedekah atas nama mayat. Menurut MTA, ritual semacam itu tidak ada tuntunannya dalam agama, kalaupun ada hadis-hadis tentang keutamaan surah Yâsîn ternyata hadisnya dâîf dan hadis tentang sedekah atas nama mayat orang salah memahaminya. Tentang masalah tablilan, MTA sendiri setuju dengan hal tersebut akan tetapi tahlilan dengan makna zikir bukan ritual yang berkembang di masyarakat Indonesia, khususnya masyarakat Jawa. Yang menjadi permasalahan adalah ritual tablilan diadakan ketika ada kematian, di mana ritual tersebut diadakan tujuh hari, empat puluh hari, seratus hari, seribu hari dan lain sebagainya. MTA beralasan bahwa ritual kematian seperti itu adalah warisan agama Hindu-Budha bukan dari Islam.

Kemudian tentang tawasul, MTA mempunyai pandangan bahwa itu merupakan sebuah jalan mendekatkan diri kepada Allah dan dalam mencari jalan untuk mendekatkan diri kepada Allah tidak melalui orang mati melainkan dengan amal saleh kita sendiri. Kemudian terkait dengan masalah talqin, MTA mempunyai pandangan berbeda dengan pandangan masyarakat pada umumnya, yakni yang dimaksud dengan talqin adalah menuntun orang yang sedang sakarat al-mant untuk mengucapkan kalimat lâ ilâha illâ Allâh bukan menuntunnya ketika mayat sudah dikebumikan. Sedangkan masalah ziarah kubur, bagi MTA, merupakan hal yang dianjurkan oleh Islam namun ziarah kuburnya hanya sekedar untuk mengingatkan kita pada kematian agar keimanan kita terus bertambah sehingga kita bisa mempersiapkan diri di hari kemudian dan ketika berziarah disunahkan mengucapkan Al-Salâm 'alaykum ya ạ̣l al-diyâr almukminîn antum salafunâ wa naḥnu lakum taba' wa inna inshâ Allâh bikum labikûn.

Terkait masalah zikir, doa berjamaah dengan suara keras, takbiran di malam hari raya, baik dalam masjid maupun keliling kampung dengan diiringi dengan musik seperti bedug dan bershalawat diiringi musik, bagi MTA, merupakan bagian dari bidah karena kesemuanya merupakan doa yang harus dilakukan dengan khusuk dan suara lirih. Namun, ketika 
seseorang dalam jamaah salat melakukan salaman setelah salat usai tidak apa-apa jika tadi sebelum salat belum salaman kanan kiri dan jika melakukannya berkali-kali (sebelum dan sesudah salat dengan orang yang sama) itu tidak ada tuntunannya dalam Islam. Begitu pula dengan menghitung zikir dengan tasbih adalah hal yang sah-sah saja jika digunakan sebagai alat menghitung bahkan tidak hanya dengan tasbih tetapi juga dengan kerikil, lidi ataupun alat hitung lainnya.

Selanjutnya tentang masalah peringatan maulid Nabi, bagi MTA sendiri berpendapat bahwa maulid Nabi adalah bidah, namun bidah maulid Nabi tersebut tidak masuk dalam urusan agama tetapi dalam urusan dunia, di mana maulid Nabi adalah satu bentuk metode dakwah Islam dan metode tersebut seharusnya dievaluasi seberapa efektif metode tersebut.

Kaitannya dengan kritik pemahaman hadis-hadis bidah, MTA tidak melakukan kritik sanad dalam mengutip hadis yang berkaitan dengan tema yang diangkat, khususnya tentang hadis-hadis bidah. MTA hanya mengutip pendapat para ulama hadis dalam kitab sharb hadisnya tentang hukum dan jarb wa ta'dîl perawi hadis. Namun, dalam memahami hadis terutama hadis-hadis bidah, MTA melakukan kritik matan yang selalu diuji dengan ayat-ayat Alquran dan hadis sahih lainnya, seperti penguiian hadis tentang salat tasbih. Menurut MTA, sebagaimana dijelaskan oleh Ahmad Sukina, bahwa hadis tentang salat tasbih tersebut bertentangan dengan Alquran, seperti QS. al-Nisâ' [4]: $48^{37}$ di mana Allah akan mengampuni dosa hambanya kecuali dosa besar (syirik). Dan secara logikanya, tidak mungkin Allah mengampuni dosa hambanya hanya karena salat sekali saja dalam seumur hidup. ${ }^{38}$ Selain melakukan kritik matan, MTA juga melakukan kritik pemahaman hadis yang menyatakan kull muḅdasâtin bidah wa kull bid'ah dalâlah wa kull dalâlatin fi al-nâr"di mana diksi kull menunjukkan makna semua atau keseluruhan dan menganggap diksi kull tersebut tidak ada takhșis atas hal baru. Kemudian, hadis Nabi yang berbunyi man sanna sunatan hasanatan..., menurut MTA tidaklah

\footnotetext{
37 "Sesungguhnya Allah tidak akan mengampuni dosa syirik, dan Dia mengampuni segala dosa yang selain dari (syirik) itu, bagi siapa yang dikehendaki-Nya. Barangsiapa yang mempersekutukan Allah, maka sungguh ia telah berbuat dosa yang besar".

38 Ahmad Sukina, Wawancara, 8 Mei 2014.
} 
memberikan indikasi bahwa bidah mempunyai dua kategori, yakni bid'ah hasanah (mahmîidah) dan bid'ah sayyi'ah (mazmûmah). Hadis tersebut hanya memberikan informasi bahwa agama Islam sangat menganjurkan umat Islam selalu termotivasi untuk membuat hal baru yang bersifat positif dalam urusan dunia saja.

\section{Penutup}

Dari uraian di atas, ada beberapa yang penulis perlu kritisi di antaranya adalah tentang takhrij al-hadîsth. Setelah melakukan studi kritis terhadap hadis-hadis tentang bid'ah yang dikutip oleh MTA, penulis sepakat dengan apa yang dijelaskan dalam buku Kumpulan Brosur Pengajian Ahad Pagi: Sunnah dan Bid'ah bahwa hadis-hadis tentang bid'ah tersebut adalah sahih dan salah satunya mawdû́: Namun, alangkah baiknya tidak hanya mengambil pendapat ulama hadis tentang kesahihan hadis, tetapi juga mengujinya terlebih dahulu agar benar-benar yakin hadis tersebut adalah sahih. Karena semua pendapat tentang kesahihan suatu hadis adalah bersifat ijtihad individual, sehingga besar kemungkinan ada kesalahan dalam berijtihad.

Selanjutnya, tentang hadis man sanna sunnah hasanah... yang dimaknai sebagai bentuk anjuran agama agar umat Islam selalu termotivasi membuat hal baru yang bersifat positif dalam urusan dunia saja, menurut penulis, kurang tepat. Jika melihat hadis lain yang berbunyi, "Barang siapa yang mengajak kepada budâ (hidayah Allah) maka baginya pahala seperti pahala orang yang diajaknya tanpa berkurang sedikit pun pahala mereka, barang siapa yang mengajak kepada dalâlah (kesesatan), maka baginya dosa seperti dosa orang yang diajaknya tanpa berkurang sedikit pun dosa mereka. ${ }^{39}$ Maka jelas sekali hadis man sanna sunnah hasanah... tidaklah terbatas pada urusan dunia saja justru melingkupi keduanya (dunia dan akhirat) dengan catatan sesuai dan memiliki representasi dalil atau bujjah dari Alquran, sunnah Nabi dan sunah para sahabat Nabi.

${ }^{39}$ Muslim, Al-Jâmi‘ al-Saḩîh, Vol. 4, 206. 


\section{Daftar Pustaka}

'Afraj (al), 'Abd AlLâh bin Husayn. Konsep Bid'ah dan Toleransi Fiqih, terj. Mohamad Taufiq Q. Hulaimi dkk. Jakarta: Al-I'tishom, 2013.

Ahmad Sukina, Wawancara, 30 Maret 2014.

Bukhârî̀ (al), Muḥammad b. Ismâîil. Al-Jâmi al-Sahẩh, Vol. 1. Kairo: Dâr Țawq al-Najâh, 1422.

Asy'ari, Hasyim. Risalah Abl as-Sunnah, terj. A. Zainul Hakim. www.kangridho.blogspot.com/diakses 03 Mei 2014.

Departemen Agama RI, Al-Qur'an dan Terjemahannya. Jakarta: Darus Sunnah, 2002.

Hamidah, Riḍâ Zakarîyâ Muhammad 'Abd Allâh. Al-Irshâd Ilâ Kayfîyah Dirâsat al-Isnâd. Kairo: Maktabah al-Imân, 2008.

Ibn al-Hajajaj, Muslim. Al-Jâmi‘ al-Ṣahîh, Vol. 2. Beirut: Dâr Ahyầ' alTurâth al-'Arabî, t.th. $\hat{1}$

Ibn Manzûur, Jamâl al-Dîn Muhammad b. Makram. Lisân al-'Arab, Vol. 8. Beirut: Dâr Șâdir, 1414.

Jinan, Mutohharun. "Kepemimpinan Imamah dalam Gerakan Purifikasi Islam di Pedesaan. Tesis-UIN Sunan Kalijaga Yogyakarta, 2013.

Majelis Tafsir Al-Qur'an (MTA). Kumpulan Brosur-Brosur Pengajian Ahad Pagi Sunnah dan Bid'ah. Surakarta: MTA [Majelis Tafsir AlQur'an], t.th.

Mawardi. "Hermeneutika Al-Qur'an Fazlur Rahman", dalam Sahiron Syamsudin (ed.), Hermeneutika Al-Qur'an dan Hadis. Yogyakarta: eLSAQ Press, 2010.

Rofiuddin. "Melarang Tahlilan, KPI Jawa Tengah Tegur Radio MTA Solo", dalam Tempo Online (28 Mei 2009).

http://www.tempo.co/read/news./diakses 29 Oktober 2013.

Pengajian Ahad Pagi pada tanggal 25 November 2007.

Pengajian Ahad Pagi pada tanggal 02 Desember 2007.

Pengajian Ahad Pagi pada tanggal 13 Januari 2008.

Pengajian Ahad Pagi pada tanggal 20 Januari 2008.

Pengajian Ahad Pagi pada tanggal 03 Febuari 2008.

Pengajian Ahad Pagi pada tanggal 10 Februari 2008.

Pengajian Ahad Pagi pada tanggal 27 Januari 2014.

Profil Yayasan Majlis Tafsir Al Qur'an (MTA), CD-ROM. 
Brosur Ahad, 09 Januari 2008 No. 1406/1446/IF tentang "Kedudukan Hadits-Hadits Fadlilah Yaasin (ke-1).

Brosur Ahad, 20 Januari 2008 No. 1407/1447/IF tentang "Kedudukan Hadits-Hadits Fadlilah Yaasin (ke-2).

Brosur Ahad, 03 Febuari 2008 No. 1409/1449/IF tentang "Kedudukan Hadits-Hadits Fadlilah Yaasin (ke-4).

Brosur Ahad, 10 Febuari 2008 No. 1410/1450/IF tentang "Kedudukan Hadits-Hadits Fadlilah Yaasin (ke-5).

Halimah, Nur, Manajemen Produksi Siaran Langsung "Tihad Pagi" di Radio Majelsi Tafsir Al-Qur'an (MTA) FM Surakarta. Yogyakarta: Fakultas Dakwah UIN Sunan Kalijaga, 2011.

Muhammad, Nur Hidayat. Benteng Ablussunah wal Jama'ah Menolak Faham Salafi, Wahabi, MTA, Hizbut Tahrir dan LDII. Kediri: Nasyrul 'Ilmi, 2011.

Mutoharoh, Dina. Perencanaan Produksi Berita di MTA TV. Yogyakarta: Fakultas Dakwah UIN Sunan Kalijaga, 2010.

Nisa', Mir'atun. Pemahaman Terbadap Al-Qur'an Dalam Rubrik. Tausiyah di Majelis Tafsir Al-Qur'an. Yogyakarta: Program Pascasarjana UIN Sunan Kalijaga, 2011.

Syafi'ah, Khulwatin. Sunnah dan Bid'ah Dalam Pandangan K.H. Hasyim Asy'ari: Telaah Terbadap Kitab Risalah Abl as-Sunnah wa al-Jama'ah. Yogyakarta: Fakultas Ushuluddin UIN Sunan Kalijaga, 2003.

\section{Software:}

Jawâmi' al-Kalim Versi 4.5.

Maktabah Shamela Versi 3.57. 